\title{
O DEBATE CONSTITUINTE: UMA LINGUAGEM DEMOCRÁTICA?
}

Tarcísio Costa

Em meados dos anos de 1980, não foram poucos os atores que cerraram fileiras em defesa de uma Assembleia Nacional Constituinte (ANC) exclusiva. A Ordem dos Advogados do Brasil (OAB) e a Associação Brasileira de Imprensa (ABI) estiveram à frente de campanha que reuniu amplo leque de organizações de classe, movimentos sociais e partidos políticos. Eram animados pela convicção de que estavam a serviço da vontade geral. Somente um foro eleito precipuamente para a função constituinte disporia da autonomia necessária para realizar o anseio coletivo de reinvenção da ordem democrática.

A causa, como se sabe, não prosperou. Prevaleceu a fórmula do Congresso com poderes constituintes, mais ao agrado dos setores conservadores. Inquietava a estes a perspectiva de uma ANC que deliberasse ao largo dos poderes constituídos, definindo instituições e normas de relevância inevitável para os gestores de plantão. Os congressistas foram eleitos para ocupar-se tanto da feitura da Constituição quanto da lide parlamentar, de maneira alternada. Estiveram sujeitos aos humores da conjuntura, ora ditados 
pelas disputas e composições partidárias, ora marcados pelo volátil e conturbado relacionamento entre o palácio do planalto e os agrupamentos políticos.

Frustrados em seu objetivo, os defensores de uma ANC exclusiva fizeram sentir seu apego a uma vontade geral originária ao longo do exercício constituinte. Foi constante o empenho em fazer reverberar a "mensagem das ruas" junto à ANC, seja na promoção das iniciativas populares e de outras formas de democracia direta, seja na valorização dos espaços abertos à presença dos grupos sociais no processo constituinte, como as audiências públicas. A expectativa desses agrupamentos era a de que, pela mobilização social, a suposta vontade popular preponderasse sobre os interesses setoriais e contingentes a que estaria sujeita a Constituinte por seu vício de origem e terminasse ditando o tom da Carta em gestação.

O desenlace é conhecido: malgrado o volume e os êxitos pontuais das emendas populares, o texto promulgado

90 foi considerado bem aquém do almejado. As inovações expressivas nas passagens dedicadas ao meio ambiente, educação e saúde - e a plêiade de direitos assegurados aos trabalhadores, aposentados, mulheres, crianças, adolescentes, idosos, índios e outras minorias, não teriam situado a Carta à altura de um suposto consenso social. A abstenção do Partido dos Trabalhadores (PT) na votação do texto constitucional evidenciou esse sentimento de frustração.

Para o PT e grupos afins, a legitimação da Carta de 1988 viria a posteriori, por pragmatismo. Logo ficou claro que a conjuntura mostrava-se cada vez menos receptiva às bandeiras que haviam sido assumidas por esses segmentos no processo constituinte. Ao invés de continuar a denunciar a Carta em nome dos objetivos não alcançados, como a desapropriação de terras produtivas para fins de reforma agrária, parecia mais consequente aderir ao texto e zelar pelas "conquistas" que estariam sob risco no campo social e no tocante ao papel do Estado e à ordem econômica. 
Assistiu-se, de fato, no pós-constituinte, ao recrudescimento das críticas veiculadas na ANC quanto às dificuldades que a Carta traria à governabilidade em momento de acentuada crise fiscal e à atividade produtiva em tempo de globalização. A Presidência da República e o Ministério da Fazenda mantiveram o refrão a respeito do impacto das novas garantias sociais e previdenciárias sobre o orçamento federal, para não mencionar o reclamo atinente ao descompasso entre as atribuições reservadas à União e os recursos a ela destinados. O rosário de queixas de analistas econômicos e agentes produtivos ia além do desconforto com o ônus representado pelas obrigações sociais e incluía restrições aos monopólios estatais e ao tratamento favorável reservado às ditas "empresas brasileiras de capital nacional" diante daquelas sediadas no Brasil, mas sob controle acionário externo.

Vinte e cinco anos após a entrada em vigor da "Constituição cidadã”, os ânimos estão serenados. As críticas do período pós-constituinte acerca do risco à governabilidade perderam sua razão de ser e os adeptos de uma ANC exclusiva são hoje amigos da Carta. Para tanto contribuíram, de um lado, a superação da crise fiscal, os ajustes na previdência, a acomodação do pacto federativo e as reformas constitucionais nos anos de 1990, e, de outro lado, a atualização do discurso do PT com o exercício do poder a partir de 2003.

É verdade que, ocasionalmente, sobretudo em períodos eleitorais, retoma-se a cantilena contra a alienação de empresas públicas, insuflada pela valorização da Petrobras após a descoberta das jazidas no pré-sal. Também são ouvidos brados de ufanismo por conta da maior projeção internacional do país. Mas são manifestações que se esgotam diante do recuo do Estado às funções menos controversas de fomentador e regulador da atividade econômica e diante das práticas continuadas de integração à economia internacional. Notam-se, obviamente, discrepâncias 
entre o governo e a oposição sobre o papel do Estado e em relação ao formato e à implementação das políticas sociais, mas são diferenças que não questionam o marco constitucional. Não se fala mais em insuficiência ou obsoletismo da Constituição.

Por que, então, retomar a discussão sobre a legitimidade do exercício constituinte, como se propõe este artigo? Qual a justificativa para indagar sobre quão legítimo foi um processo deliberativo responsável por texto que, com as emendas recebidas, revelou-se eficaz como referência normativa de um período particularmente intenso da história política e econômica do país? Por duas razões, complementares entre si. A primeira é de natureza conceitual e a segunda, de cunho histórico.

As análises sobre a legitimidade do processo constituinte costumam ser variações em torno do juízo de que se tratou da mais ampla e participativa experiência deli-

92 berativa de nossa história republicana, independentemente do critério que se privilegie: partidário, classista, profissional, regional ou étnico. Por vezes se argumenta que foi a estrutura capilarizada do processo que permitiu uma ausculta diversificada da cidadania, com a ressalva de que o percurso traçado foi desvirtuado com a alteração do regimento interno da ANC feita pelo "Centrão". Mas pouco se diz sobre a deliberação em si. Como se, asseguradas a representatividade das audiências e a fluidez dos ritos, o resultado inevitável fosse o resgate ou a explicitação de uma pré-definida vontade coletiva. Quanto mais inclusivo fosse o foro e isentos seus procedimentos, maior seria a chance de ter revelada a vontade geral, que se sabia latente ${ }^{1}$.

\footnotetext{
${ }^{1}$ Como análises que ressaltam o caráter participativo e a representatividade partidária e regional do exercício constituinte, ver Sampaio (2009) e Kinzo (1990), respectivamente.
} 
Existem, contudo, caminhos alternativos e de interesse histórico para pensar a legitimidade democrática. Teóricos de diferentes filiações optam por amparar a legitimidade da ação política não em uma vontade geral imanente, mas no processo deliberativo de definição do interesse coletivo. Mais do que isso: há uma reflexão consolidada, como expressa por Jürgen Habermas e Bernard Manin, sobre como fundamentar a legitimidade democrática na qualidade da deliberação, que se supõe que seja um exercício em aberto, pluralista e sem sujeitos oniscientes. Embora não tenham igual especificidade, análises sobre a transição democrática no Brasil também colocaram em pauta a compreensão da democracia como um processo deliberativo e indeterminado.

O ganho que a leitura do exercício constituinte sob essas lentes propicia é múltiplo. Torna-se possível aferir os limites e as potencialidades do ambiente discursivo em que foram desenvolvidas as tratativas da ANC. Oferece também a oportunidade de examinar em que medida o discurso político brasileiro no final dos anos de 1980, quando se dava por concluída a transição, refletia valores democráticos. O diagnóstico que faziam estudiosos como Francisco Weffort era o de que a linguagem democrática era de uso cada vez mais corrente tanto à esquerda como à direita do espectro político, leitura digerida com grão de sal por observadores mais céticos de nossa cena política, como Albert Hirschman.

$$
* * *
$$

Do contratualismo liberal à teoria crítica, tem sido prolífica a reflexão sobre o tema da deliberação pública. Rawls (1971) é paradigmático entre os contratualistas, mas não é o caso de resenhá-lo aqui em toda sua amplitude ${ }^{2}$.

\footnotetext{
${ }^{2}$ Ver Rawls (1971), em particular os capítulos I, II, III e IV.
} 
Convém recordar, de todo modo, que Rawls dedica-se em sua obra à identificação dos princípios que os indivíduos se imaginados sob um "véu de ignorância" que lhes assegure absoluta imparcialidade em seus juízos - escolheriam para fundamentar uma concepção racional e universalmente aceita da justiça. Também reflete sobre a "estrutura (institucional) básica" que seria a mais adequada para colocar esses princípios em prática ${ }^{3}$.

A todos é reconhecido igual direito de participação no processo político e na determinação de seus resultados, o que pode ser comprometido por distorções no modelo representativo e pelos vícios do sectarismo e do abuso do poder econômico. Para impedir a sobrerrepresentação, Rawls ressalta a importância de que os distritos eleitorais sejam de dimensões equivalentes, com quocientes de votos semelhantes para a eleição dos representantes. De modo a evitar que a deliberação pública fique refém das facções, 94 advoga o franco usufruto das liberdades de pensamento e de consciência, bem como dos direitos de reunião e de expressão, inclusive da prerrogativa de "leal oposição". Contra o abuso econômico, são prescritas desde uma equitativa distribuição da riqueza até o financiamento público dos partidos políticos.

Rawls deixa claro que não há, contudo, como tornar a deliberação política imune a desvios. Afinal de contas, ela

\footnotetext{
${ }^{3}$ Por ordem de prioridade, são dois os princípios concebidos na "posição original". O primeiro requer que sejam garantidas a todos as liberdades fundamentais. O segundo recomenda que as desigualdades sociais e econômicas sejam acomodadas segundo um arranjo tal que, respeitados a igualdade de oportunidades e o interesse das gerações futuras, os maiores benefícios destinem-se aos menos afortunados. A ordem constitucional construída a partir e em defesa desses princípios teria uma feição liberal-democrática. Por um lado, contemplaria uma carta de direitos sob amparo da lei, um sistema representativo, equilíbrio e controle recíproco dos poderes e um legislativo bicameral. Por outro lado, o Estado seria dotado de legislação e meios para assegurar livre-competição, pleno emprego, renda social mínima, ensino (público ou subsidiado) e políticas distributivas por intermédio de taxação e ajustes ao direito de propriedade (Rawls, 1972).
} 
se dá em ambiente necessariamente conflituoso, no "mundo imperfeito". Por mais que sejam facultados a todos os atores o mais equânime acesso às informações disponíveis sobre a realidade e condições semelhantes para apresentar, apreciar e reformar propostas normativas, não se concebe que o arranjo constitucional possa ser tão imparcial quanto o contrato social que pautou a seleção dos princípios basilares de justiça. Enquanto a deliberação constituinte é interativa, com barganha e negociação, aquela desenvolvida na “posição original”, não, já que pressupõe unanimidade de pontos de vistas.

Há quem questione se é propriamente deliberativa a definição dos princípios de justiça sob o "véu de ignorância". Rawls prevê a existência de um "árbitro", que mediaria a interlocução dos atores, anunciando as opções disponíveis e os argumentos a favor de cada uma delas. Mas logo conclui que o papel desse árbitro é supérfluo, uma vez que todos devem pronunciar-se na mesma linha. Desconhecendo tudo aquilo que os diferencia entre si e tendo em mãos idênticas opções e critérios de juízo, os indivíduos são fadados à convergência de posições. A visão de qualquer ator escolhido ao léu reflete a orientação dos demais. O processo de escolha resume-se, assim, a um simples cálculo em que opções comuns passam pelo crivo de critérios igualmente comuns, com o resultado já contido na premissa.

Não surpreende, assim, que as críticas a Rawls tenham sido concentradas no irrealismo do modelo ancorado na "posição original”, que sobreviveria enquanto parâmetro normativo para o uso público da razão, mas seria demasiado asséptico para comandar a "estrutura básica" e assegurar a estabilidade desta. Em obra subsequente, Rawls busca dotar sua construção teórica de maior efetividade; complementa a teoria moral da justiça com uma concepção política da justiça, que estaria melhor aquinhoada para 
fundamentar o pluralismo doutrinário contemporâneo (Rawls, 1993) ${ }^{4}$.

Entre os pontos que distinguem Jürgen Habermas de John Rawls, dois traços da teoria da ação comunicativa elaborada pelo primeiro, são de relevância imediata para o debate sobre deliberação: a articulação mais estreita de pressupostos filosóficos com uma compreensão crítica da sociedade e a natureza "dialógica" da produção do conhecimento".

Ao valorizar uma síntese dialética entre filosofia e interpretação social, entre norma e fato, Habermas é fiel ao espírito que pautou a fundação do Instituto de Pesquisa Social de Frankfurt, imbuídos como foram seus pioneiros da missão de investigar em situações históricas concretas o potencial emancipatório da razão. Sabe-se que o ceticismo provocado por fenômenos como o nazifascismo e o totalitarismo soviético arrefeceu o ânimo da teoria crítica com a investigação social. Adorno refugiou-se na 96 "dialética negativa", com pessimismo crescente quanto à possibilidade de resistir à ascendência crescente da razão instrumental, alheia aos fins. Habermas não o seguiu. A consciência do Holocausto ("desumanidade realizada coletivamente”) já o fizera imergir na tradição crítica alemã, de Kant a Lukács, passando por Schelling, Hegel e Marx, em busca de inspiração para dissecar a "patologia da modernidade" e poder revalidar a relevância do uso da razão contra formas abertas ou dissimuladas de dominação e opressão.

\footnotetext{
${ }^{4}$ Mediante a elaboração de conceitos como o "consenso superposto" (overlapping consensus), o novo paradigma rawlsiano busca maior assentamento na realidade de modo a servir de referência a que doutrinas filosóficas, religiosas e morais reconhecidamente incompatíveis entre si - possam coexistir, desde que confirmada sua "razoabilidade", ou seja, o respeito aos ritos de um regime democrático. Trata-se, enfim, de um marco mais afim à natureza da "estrutura básica", que não prescinde, de todo modo, da exigência da unanimidade. Ver Rawls (1993), em particular o lecture IV.

${ }^{5}$ Ver Habermas $(1986,1996)$, em particular, o capítulo VII do segundo.
} 
Na crítica que faz da razão ou de sua "realização deformada na história", Habermas desenvolve uma tipologia das formas de reflexão inscritas nas práticas e instituições sociais. A racionalidade da ação propositiva seria característica dos agregados ou complexos sociais. Implica que as ações e sistemas sociais podem ser racionalizados pelo uso eficiente da técnica e pela consistência das escolhas valorativas. Nortearia as ciências analítico-empíricas. Uma racionalidade instrumental é o que se avalia pelo êxito na obtenção de resultados e metas. Já a racionalidade da ação comunicativa seria associada à realidade efetiva, com sua multiplicidade de atores. Requer a superação das distorções e relações de dependência que dificultam a superação pelo diálogo dos conflitos e desajustes sociais. Seria inerente às ciências "reconstrutivas", como a própria teoria da ação comunicativa ou "pragmática universal". Trata-se de uma racionalidade que visa assegurar confiança e entendimento mútuo entre os indivíduos.

Embora a compreensão dos sistemas requeira o entendimento do papel dos atores sociais e vice-versa, as duas racionalidades não têm coexistido de modo harmônico, constata Habermas (1986). A dinâmica da sociedade industrial, com os constrangimentos crescentes impostos à ação dos indivíduos, tem dado margem à sujeição da realidade social à lógica sistêmica, à hegemonia da razão instrumental já denunciada por Weber e Adorno. Mas Habermas está convencido de que tal fenômeno não é necessário ou inelutável. Confia na função liberadora de uma ação comunicativa ou dialógica sem peias. Até porque a instrumentalização da realidade tem sido seletiva, parcial. A racionalidade comunicativa resiste em múltiplas formas, desde os princípios universalistas das modernas constituições até a pauta dos movimentos sociais. Basta reunir as condições econômicas, políticas e sociais para que se adote como regra para a resolução de conflitos "a força do melhor argumento", a ser validado segundo os critérios da 
compreensibilidade (da expressão simbólica), da verdade (do conteúdo da proposição), da sinceridade (da intenção) e da correção (normativa) dos atos de fala ${ }^{6}$.

Uma nota final sobre Habermas e a legitimidade democrática: o elogio ao diálogo não dispensa a expectativa do consenso. É certo que o diálogo não se dá entre sujeitos autossuficientes que interagem em defesa de verdades pré-definidas. Ao buscar empréstimo na filosofia da linguagem dos atos de fala e, refinando-os, dar sua "guinada linguística", no dizer de Richard Bernstein (1985), Habermas abriu mão da hermenêutica do sujeito. Os atores são constituídos por meio e no âmbito da própria ação comunicativa. E, obviamente, os conflitos e as acomodações de posição são corriqueiros no curso da pragmática universal. Mas, se um argumento é questionado e remetido ao plano do discurso para confronto com um dos critérios de validade, a solução há de ser consensual, por conta do próprio universalismo dos critérios.

Se em vários aspectos converge com Habermas, aqui Bernard Manin dele se afasta, pela incisiva rejeição à unanimidade como base de legitimidade para a deliberação (Manin, 1987). Para Manin, o requisito de assentimento unânime dos cidadãos é irrealista e, por isso, impróprio para amparar uma experiência democrática. Pode servir de base para teorias normativas sobre o que é ou não é justo, como ambiciona Rawls, mas não de critério de legitimidade para processos de tomada de decisão em regimes democráticos, que soem ocorrer com a marca da premência e sob o signo da incerteza.

\footnotetext{
${ }^{6}$ É verdade, admite Habermas, que nas situações concretas as divergências costumam ser contornadas por uma plêiade de artimanhas e estratégias. Mas o importante é que a via da argumentação não coercitiva esteja inscrita como possibilidade real em nossos discursos teóricos, práticos e estéticos. Mais do que isso: os critérios de validade valem igualmente para a comunicação pré-teórica, para os conceitos e estruturas básicas que sustentam o uso público da razão. A apriorística posição original rawlsiana não cabe em Habermas. Não apenas o conhecimento, mas também as condições para sua formação são sujeitos à validação empírica.
} 
Manin detém-se na premissa de que, nem os cidadãos, nem seus representantes atuam na arena política com vontades ou preferências definidas a priori. Todos partem de posições tentativas, até porque as informações disponíveis são incompletas e fragmentadas. No curso da deliberação, os atores costumam obter uma maior familiarização com os temas, o que os habilita a aprimorar seus juízos, incorporar novos pleitos, rever posições ou prioridades. Não é incomum que identifiquem inconsistências e até incompatibilidade entre suas próprias preferências ${ }^{7}$.

A natureza da argumentação em um processo deliberativo tampouco condiz com o critério da unanimidade, acrescenta Manin. Os argumentos são construídos de modo racional e discursivo não para comprovar ou demonstrar um achado sociológico, mas para persuadir o interlocutor. O ponto de partida é contingente. Não se elabora sobre premissas evidentes ou convencionais, mas a partir de proposições que reflitam valores supostamente partilhados pela audiência. $\mathrm{O}$ discurso é modulado pela percepção que se tenha das opções do público-alvo, que não são, por regra, universais, embora a isso se aspire. Ao invés de obedecer a qualquer imperativo lógico, o enlace das proposições é feito por analogia ou a fortiori. Desse arranjo podem advir argumentos plausíveis, convincentes, mas jamais necessários. Nem é pertinente a inquirição se são estes, empiricamente, verdadeiros ou falsos. Serão aferidos segundo sua consistência e eficácia como recurso argumentativo. Trata-se, enfim, de uma argumentação afinada com a própria essência da política, assemelhada a um "conflito entre os deuses",

\footnotetext{
7 Manin exemplifica com as expectativas de redução de tributos e de melhoria dos serviços públicos. Com a evolução do debate, o interessado pode dar-se conta de que a satisfação plena de uma dessas expectativas implicará o sacrifício da outra e passar a defender uma acomodação entre os dois anseios que inicialmente não cogitava. Se considerarmos que situações do gênero podem ocorrer várias vezes com inúmeros atores em cada experiência deliberativa, torna-se óbvia a improbabilidade de que se tenha como desenlace uma convergência absoluta de posições.
} 
cujo encaminhamento deve ser realizado não por escolha arbitrária, como propunha Weber, autor da expressão, mas segundo justificativas consideradas aceitáveis pela maioria.

A voz da minoria não é negligenciada, esclarece Manin. Rechaça a leitura rousseauniana de que a minoria representa apenas uma opinião equivocada sobre o interesse comum, ou seja, o entendimento de que, se esclarecidas ou mais informadas, as vozes minoritárias identificar-se-iam com a definição dada pela maioria sobre o que é a vontade geral. Para Manin, a minoria é o que ela expressa ser: uma visão diferente daquela dominante, que deve ser devidamente contabilizada pelos gestores de plantão, até para que o poder seja exercido sem maiores arestas.

A existência de minorias em nada afetaria a legitimidade da democracia. Apenas confirma a necessidade de que ela seja compreendida em termos distintos dos apregoados por Rousseau e, paradoxalmente, por Rawls. Ao invés 100 de assentar a legitimidade em um somatório de vontades idênticas e pré-definidas, cabe repousá-la, acentua Bernard Manin, sobre o processo deliberativo de definição do interesse comum. Em outras palavras, a legitimidade democrática é ancorada não em uma vontade geral, mas em uma deliberação geral (respeitadas as exceções constitucionais quanto ao direito de voto), que é, por essência, conflituosa, indefinida e sem sujeitos oniscientes.

$$
* * *
$$

A reflexão sobre a democracia no Brasil não foi indiferente ao tema da deliberação. Embora inexistam estudos específicos de maior realce, as condições e princípios de uma experiência deliberativa receberam, em diferentes momentos, a atenção de analistas da transição democrática. Ainda no limiar do período mais repressivo do regime militar, Fernando Henrique Cardoso fez uma 
profissão de fé na autonomia da política ao defender o reconhecimento da legitimidade do conflito como passo indispensável para a construção de uma "democracia substantiva" (Cardoso, 1975) ${ }^{8}$. Já em plena transição, Carlos Nelson Coutinho (1980) recorre a Gramsci para defender que a esquerda considere os atributos liberal-democráticos como essenciais na luta pela hegemonia na sociedade e no Estado. Nos estertores do regime militar, trata-se da vez de Francisco Weffort afirmar que a linguagem da democracia é de uso cada vez mais corrente entre conservadores e progressistas, até por conta do trauma causado pelo uso da violência durante a ditadura militar (Weffort, 1985).

O elogio de Cardoso à política é casado com a crítica às explicações deterministas do autoritarismo. Assim como o regime militar não teria sido imposição da lógica de acumulação capitalista, sua superação dependeria de escolhas políticas, sem pressupostos econômicos. O alegado "milagre econômico" dos anos de 1970 não se sustentou na contenção de gastos públicos via repressão política das demandas, mas, ao contrário, em expansão da capacidade produtiva por conta de investimentos públicos e privados, argumenta Cardoso (1975). A repressão teria sido responsável, quando muito, por características do modelo, como a concentração de renda. O regime ter-se-ia beneficiado do cenário legitimador da Guerra Fria, que estava perdendo nitidez com a distensão entre as potências nucleares e o abandono por Cuba da política de apoio aos movimentos de guerrilha. Como âncora para o sistema de poder, restava um "apático comodismo social”, o que era claramente insuficiente para assegurar a atualização reclamada pelos desafios domésticos e internacionais.

\footnotetext{
${ }^{8}$ São particularmente relevantes a introdução ("O autoritarismo e a democratização necessária") e o capítulo conclusivo ("A questão da democracia”) do livro.
} 
Duas vias poderiam ser cogitadas para a liberalização política. A primeira consistiria na presença de um "déspota esclarecido", que se revelasse convencido de que qualquer projeto de "segurança nacional" sem o apoio de uma cidadania ativa implicaria apenas o reforço de um Estado a serviço da minoria. Seria o caminho talvez mais curto, mas pouco confiável, por ser tutelado, pondera Fernando Henrique Cardoso. A segunda e mais promissora via seria uma aproximação negociada entre segmentos realistas do regime e setores da oposição em torno da necessidade de legitimação do conflito. Isso implicaria o reconhecimento pelos atores interessados de que não haveria alternativa ao obsoleto autoritarismo vigente sem renúncia às visões mistificadas e pseudoconsensuais de futuro, seja o lema do Brasil-potência, seja o sonho de um igualitarismo iminente. A admissão da divergência como legítima tampouco se coadunaria com a suposição

102 de que qualquer dos contendores tivesse consigo a chave da história. Seriam inoportunas tanto a pretensão de que a estrutura do Estado pudesse absorver a variedade dos interesses sociais, como a ilusão de que um partido ou agrupamento político falasse pela coletividade como um todo, acrescenta Cardoso.

Ainda que não estivesse ao alcance da mão, o objetivo último da liberalização seria uma "democracia substantiva", cuja realização passaria necessariamente pela restauração dos direitos civis e políticos, sem o que a sociedade ficaria impotente para exercer o controle devido sobre o Estado. Isso não se confundiria com "basismo", ressalta Cardoso. Os sindicatos, organizações de classe, agrupamentos étnicos e os movimentos sociais seriam úteis por contrapor à tradição elitista e conservadora uma "atitude ética de solidariedade". Mas não se revelavam capazes de pensar o conjunto social e o próprio Estado. Limitavam-se a criar "espaços de liberdade" para os setores que repre- 
sentam, deixando a máquina pública como chasse gardée dos setores dominantes (Cardoso, 1975) ${ }^{9}$.

A leitura de Fernando Henrique Cardoso não ficou isenta de crítica entre os pares da resistência democrática. Merece menção a análise desenvolvida por Coutinho (1980). A obra é considerada um paradigma na conversão de intelectuais e personalidades identificadas com o Partido Comunista Brasileiro, de uma leitura instrumental da democracia, para a aceitação dos valores liberal-democráticos como essenciais, ainda que insuficientes para a instauração do socialismo ${ }^{10}$. A democracia deixa de ser considerada como forma de dominação por parte da burguesia ou dos monopólios nacionais e internacionais e passa a ser vista como base insubstituível e fundamental para o estabelecimento e consolidação de um modelo socialista. Só que isso requer não a legitimação do conflito, que equivaleria a uma simples rendição ao liberalismo, mas a criação de um "consenso majoritário" mediante uma persistente e ampla "guerra de posição" na sociedade e também no Estado.

Para Coutinho, as mudanças políticas no país sempre se deram pela "via prussiana", com a prática da conciliação de elites e a reprodução ampliada de um quadro de depen-

\footnotetext{
${ }^{9}$ Daí a importância de que a necessária reativação das liberdades públicas, do voto e da dinâmica partidária seja acompanhada de mecanismos que permitam o controle do Estado também internamente, afirma Cardoso. Onipresente na vida nacional em suas funções de produtor e regulador, o Estado precisaria ser monitorado a partir de dentro. O sociólogo cogita desde a quebra do segredo de informação em assuntos de relevância pública até a democratização dos mecanismos de tomada de decisão em diferentes núcleos de poder da administração e das empresas estatais. Os grupos privados também deveriam ser sujeitos à auditoria pública nas atividades de interesse coletivo. Reanimada a sociedade e controlado o Estado, poder-se-ia perseguir, deliberativamente e não segundo a racionalidade tecnocrática, uma utopia com ressonância social, que incluiria as bandeiras dos movimentos civis contemporâneos e as múltiplas expectativas de uma população carente como a brasileira. Para a visão de Cardoso sobre a natureza do papel a ser desempenhado pelos movimentos sociais, ver Cardoso (1993, pp. 257-72).

${ }^{10}$ Sobre a evolução do pensamento da intelectualidade associada ao Partido Comunista Brasileiro a respeito da democracia, ver Brandão (1997).
} 
dência. Da proclamação da Independência por um príncipe português à implantação, pelo regime militar, de uma modalidade dependente de capitalismo de Estado, sobressai a tendência à exclusão das massas dos frutos do progresso e da participação nos processos de tomada de decisão. A resposta da esquerda concorreu para a debilidade dos ensaios democráticos no país. Optara-se desde sempre pelo recurso igualmente prussiano do "golpismo", tanto como concepção de acesso ao poder como enquanto modo de fazer política. A estratégia era dirigida à "tomada" do Executivo para a realização das reformas estruturais, ao arrepio de qualquer consideração pelo Parlamento, visto como uma instituição desconectada da relação de forças na sociedade. O assédio ao poder e a própria condução das lides partidárias eram feitas com sofreguidão "pelo alto", sem ausculta às bases sociais.

Insistindo em que a questão democrática consta na 104 agenda do comunismo brasileiro desde 1958 e foi inscrita no pensamento de esquerda pelo jovem Marx, sem prejuízo da maioridade que ela assumiu em Gramsci e Berlinguer, Carlos Nelson Coutinho advogava que a ruptura do padrão prussiano de transformação política passa pela aceitação definitiva da democracia como valor universal, o que conservaria e elevaria a nível superior as conquistas liberais. Tal desafio comporta dois eixos que se reforçam mutuamente: a democratização da economia nacional e a socialização da política. A economia passará de oligárquica a democrática à medida que sejam realizadas a reforma agrária, a integração e ampliação do mercado interno e o fim dos monopólios. Já a socialização da política, argumenta Coutinho, é favorecida pela diferenciação social e cultural ocorrida com a modernização conservadora sob mando militar a partir dos anos de 1960, com a emergência de uma multiplicidade de sujeitos coletivos, como as comunidades eclesiais de base e os movimentos sociais identificados com as causas ecológi- 
cas e de gênero. Também teria concorrido para a afirmação da sociedade civil a autonomia crescente diante do Estado de que passaram a gozar as centrais sindicais e as organizações de classe, a exemplo da OAB e da ABI.

Não se trata, contudo, de um elogio ao pluralismo per se. Ele é saudado enquanto desdobramento indispensável à construção de um "consenso majoritário" - tático em um primeiro momento - que permita a liberação política com a definição, por uma ANC, de novas "regras do jogo" e estratégico no momento subsequente - o aprofundamento da democracia no sentido de uma experiência organizada de massas. A expectativa é a de uma persistente "guerra de posição" em que não seria menor o papel de partidos operários e do próprio Parlamento ${ }^{11}$.

Carlos Nelson Coutinho fala em "unidade na diversidade". Respeitados a variedade de interesses e o direito de expressão da minoria, o desafio é congregar o consenso necessário para dar cabo, em cada quadra histórica, dos desafios econômicos e sociais que se coloquem no caminho da afirmação de um socialismo democrático no Brasil, que se distingue, ressalta Coutinho, da social-democracia. Aqui a crítica a Fernando Henrique Cardoso torna-se explícita. Contestando a associação feita pelo sociólogo em entrevista recente entre consenso e autoritarismo, afirma que Cardoso se fizera intérprete de uma social-democracia confinada ao horizonte do liberalismo. Negar o valor do consenso

\footnotetext{
${ }^{11}$ Inspirado nas reflexões de Palmiro Togliatti sobre o "partido novo", Coutinho (1980) argumenta que a existência de um partido comprometido com a renovação social e, como tal, sensível aos pleitos dos movimentos de base, é crucial para a formação de um bloco democrático e nacional-popular, com atuação relevante fora e dentro do Parlamento. Fora, enquanto instância de pressão e controle social. Dentro, para assegurar que os mecanismos de representação indireta, nos três níveis da Federação, escapem aos interesses corporativos e concorram, efetivamente, para uma "síntese política" entre os sujeitos coletivos. Quanto mais forte o bloco e consolidada a democracia de massas, maiores as chances de o Parlamento "corporificar" a progressiva hegemonia das classes trabalhadoras na vida política brasileira.
} 
em nome do reconhecimento da legitimidade do conflito seria negar a necessidade da hegemonia para a democracia. Para Coutinho, Cardoso conservara, mas não elevara as conquistas liberais. Ter-se-ia limitado a uma valorização abstrata do pluralismo, ignorando o ritmo dialético do movimento social.

Weffort (1985) retoma o juízo de que a experiência democrática é, por natureza, conflituosa e indeterminada e acrescenta que disto estaria convencido um universo cada vez mais amplo de cidadãos e atores políticos, malgrado o contexto de crise. A estagnação econômica tivera um elevado custo social. Mas ao contrário do que ocorrera nos anos de 1960, não era mais corrente, nos círculos de esquerda, a defesa da revolução. Do lado dos "donos do poder" tampouco se pregava a perpetuação indefinida do arbítrio. Salvaguardadas as diferenças quanto ao ritmo e à substância da transição democrática, havia uma clara convergência quanto à impor106 tância do processo e de que chegasse a bom termo.

A explicação dada por Weffort para esse sentimento comum vale para os militares e seus opositores: o trauma da violência. Nenhuma das partes aceitava como cenário o retorno aos anos de chumbo. Além da comprovada e absoluta ineficácia da luta armada, a acusação de que usara as mesmas armas do adversário revelava-se politicamente nociva para esquerda. Quanto às lideranças do regime, estavam mais do que cientes da desilusão causada pelo terror e pela corrupção nos setores civis que haviam pactuado com a ruptura da ordem constitucional em 1964.

Francisco Weffort preocupa-se em deixar claro, de todo modo, que a improbabilidade do retrocesso não era garantia do avanço. Não estaria inscrito em lei histórica alguma que a transição daria lugar a uma plena e consolidada democracia. A política, insiste Weffort, é um processo em aberto, uma cosa da fare. Pensar o contrário seria acalentar o viés autoritário de guiar ou determinar a história.Assim 
como a deterioração da crise econômica e social na primeira metade dos anos de 1980 não impedira a transição, a política continuaria a seguir o rumo que viesse a ser negociado entre seus atores. Para que o desenlace fosse o desejável, muito contribuiria a renúncia explícita por ambos os lados a uma concepção instrumental da democracia, ou seja, o repúdio ao golpismo, vício cuja autoria é atribuída não à esquerda, mas às elites nacionais ${ }^{12}$.

Multiplicavam-se as evidências, insiste Weffort, do compromisso permanente e não apenas tático de liberais e socialistas com a democracia, ainda que houvesse divergência sobre o ponto de chegada. Os liberais almejavam apenas a satisfação das demandas da frente democrática: restauração das eleições diretas em todos os níveis, restabelecimento pleno das prerrogativas do Congresso, afirmação da independência do Judiciário, revogação da Lei de Segurança Nacional, garantia da liberdade e da autonomia sindical e desativação da comunidade de informação. Já a esquerda não podia contentar-se com a simples consolidação do Estado de direito, que, embora necessária e indispensável, não asseguraria, por si só, que a democracia resultasse significativa melhora para o pobre. Cumpria criar condições para uma erradicação em massa da pobreza, que privava milhões do acesso à cidadania. Sem isso, o Brasil seria, quando muito, uma democracia de "cidadãos de segunda classe".

Só que a correção das desigualdades sociais não se daria por conta exclusiva das instâncias representativas.

\footnotetext{
${ }^{12}$ Weffort passa, então, a listar as ocasiões em que os grupos dirigentes julgaram que o sistema representativo não mais atendia a seus interesses de conservação do poder econômico e social e decidiram "virar a mesa", em que inclui, limitando-se ao pós-1930, a Revolução Constitucionalista de 1932, a instauração do Estado Novo em 1937, o movimento integralista em 1938, as tentativas de impedir a posse de Vargas em 1950 e a de Juscelino em 1955, as manobras que antecederam o suicídio de Vargas em 1954, o veto a Café Filho em 1955, o esforço em impedir a posse de João Goulart em 1961 e o golpe de 1964. A esquerda, admite Weffort, teria lançado mão do expediente sem igual assiduidade, mas com desembaraço, como na Intentona de 1935 e no questionamento a Dutra em 1947.
} 
Ao lado do pluralismo partidário, caberia zelar pelo pluralismo social. Somente a ação conjugada dos partidos populares com os movimentos sociais poderia servir de contrapeso à ascendência das forças conservadoras sobre as políticas de Estado, condição sem a qual não se criaria, acentua Weffort, uma democracia efetiva. Não se requeria para tanto o apelo de qualquer modelo de sociedade a ser consumado em algum momento futuro. Os "slogans vazios" deviam dar lugar à disposição de enfrentar desafios pendentes do capitalismo, a serem equacionados no marco do próprio sistema, como a adequação das políticas econômicas às preocupações sociais. Assim como o poder não é algo a ser tomado de assalto, mas sim o resultado de uma conquista cotidiana, a busca de uma sociedade mais justa não deve ser adiada sine die, como objetivo inscrito em um tempo remoto, mas enquanto meta realizável a partir das circunstâncias presentes.

108 É sustentável afirmar, portanto, que, às vésperas da convocação da ANC, reconhecidos intelectuais convergiam quanto ao entendimento de que os institutos representativos e os direitos e garantias individuais são ingredientes essenciais da democracia. Também coincidiam no juízo de que deveria haver uma simbiose entre democracia e mudança social de modo a assegurar o acesso de milhões de brasileiros à cidadania. Nem Cardoso, nem Coutinho e tampouco Weffort negavam que o liberalismo tivesse sido usado como fachada para práticas autocráticas e excludentes, mas viam esse vício não como uma necessidade histórica ditada pela evolução do capital, mas como resultado de opções políticas.

A cartilha, contudo, não era exatamente a mesma. Enquanto Coutinho atinha-se a noções como unidade na diversidade, consenso majoritário e sujeitos da história, Cardoso e Weffort adotavam leituras menos "orgânicas" e mais sintonizadas com o debate internacional sobre transi- 
ções democráticas ${ }^{13}$. Cada um a seu modo, compreendiam a política como um processo essencialmente indeterminado, cujas regras são passíveis de redefinição sempre que seja essa a escolha, deliberativa, da maioria. Não haveria, por conseguinte, leis ou marchas da história que se imponham aos agentes políticos. Tampouco cogitavam de guias, individuais ou coletivos, que tenham presciência hermenêutica ou política do futuro, até porque este estaria, por definição, em aberto. Cardoso e Weffort adotavam ênfases distintas quanto ao papel dos movimentos sociais. Se para Cardoso eles eram úteis para a difusão de uma ética da solidariedade, mas ineptos para a tarefa de pensar e transformar o Estado, Weffort considerava-os fundamentais para assegurar o pluralismo social e o aprofundamento da democracia.

Alguns meses após a publicação de Por que democracia?, Albert Hirschman, em seminário realizado em São Paulo sobre o tema da consolidação democrática, mostrou-se cauteloso em seus prognósticos sobre o futuro da democracia no Brasil ${ }^{14}$. Reconheceu que o ritmo da transição não havia sido comprometido pela recessão econômica e pelo crescimento do desemprego. Saudou também o fim da censura e a devolução gradual do poder político a autoridades eleitas. Mas não julgou tais fatores suficientes para definir seu ânimo. Serviam, quando muito, para atenuar seu pessimismo, sentimento que devia ser o ponto de partida para

\footnotetext{
${ }^{13}$ Entre os estudiosos sobre transições democráticas então em evidência, destacaria, pela atenção atribuída à incerteza ou indeterminação como característica dos experimentos democráticos, o nome de Adam Przeworski, autor, entre outras obras, de Democracy and the market.

${ }^{14}$ Essa apresentação no seminário em tela foi publicada como capítulo em Hirschman (1992, pp.176-82). Para o tratamento dado por ele ao tema da deliberação, inclusive com referência ao trabalho de Bernard Manin, ver Hirschman (1991, pp.164-70). Também é relevante Hirschman (1995, pp.77-84).
} 
qualquer reflexão séria sobre as perspectivas da democracia na América Latina, tamanha a instabilidade que caracterizava as experiências políticas na região, inclusive aquelas de cunho autoritário. Não descartava a possibilidade de que estivesse assistindo apenas à desintegração de um autoritarismo que se presumia sólido, sem o prenúncio de qualquer alternativa estável no futuro imediato.

Para Hirschman, seria fútil definir pré-condições para o enraizamento da democracia na região e, em particular, no Brasil. Além da tradição de instabilidade política, os inibidores multiplicavam-se, como a vulnerabilidade econômica e a injusta estrutura social. Para evitar que se terminasse condicionando o usufruto da democracia à mudança da realidade como um todo, seria mais consequente investir não no que parecia provável, mas no que se afigurava possível. Em outras palavras, Hirschman defendia que, ao invés de ater-se à identificação e à viabilização de requisitos

110 supostamente necessários e suficientes para a consolidação da democracia, seria preferível atentar às oportunidades que a conjuntura oferecia para sedimentar os valores que norteiam a experiência democrática, como a tolerância e o respeito à diferença.

O desafio assumiria uma relevância particular diante de um renitente viés da cultura política latino-americana, qual seja, o apreço pela assertividade ou opiniões definitivas (opinionated opinions) sobre todo e qualquer item da agenda pública (Hirschman, 1992, pp. 180-1). É clara a dissonância deste e de outros traços afins com a mentalidade que Hirschman julgava adequada ao jogo democrático, reportando-se à visão de Bernard Manin e, em especial, ao entendimento de que o exercício deliberativo se faz a partir de posições tentativas e não de juízos conclusivos ou previamente arrematados.

Albert Hirschman é uma citação oportuna, não somente por qualificar o otimismo expresso por Francisco Weffort 
quanto ao grau de disseminação no país de uma linguagem democrática, mas por prover instrumental teórico relevante para aferição da qualidade da deliberação política na experiência constituinte. Trata-se do conjunto de arquétipos elaborados na sua instigante revisão do pensamento conservador a respeito da evolução dos direitos e garantias individuais e da reação correspondente no campo progressista (Hirschman, 1991) ${ }^{15}$.

Os argumentos utilizados contra cada nova onda de direitos são organizados por Hirschman em três teses, que denomina "perversidade", "futilidade" e "ameaça". As respostas dos partidários dos avanços são agrupadas em tipos definidos à parte: voluntarismo franco; cumplicidade da história e ilusão da sinergia, respectivamente.

A tese da perversidade argumenta que a adoção dos novos direitos tende a produzir efeitos opostos àqueles buscados. Teria feito fortuna ao longo da história entre aqueles que se opuseram aos direitos sociais. Desde os críticos das Poor Laws na Inglaterra vitoriana aos libelos contra o sistema do bem-estar social nos Estados Unidos dos anos de 1980, buscou-se amparo no entendimento de que as garantias ao trabalhador estimulam a indolência e terminam por comprometer a qualidade de vida do beneficiado. Hirschman atribui o prestígio da tese à afinidade desta com a sequência Húbris-Nêmesis da mitologia grega, em que o sucesso gera arrogância e, por intervenção divina, fracasso e desastre ${ }^{16}$.

\footnotetext{
${ }^{15} \mathrm{O}$ ensaio de Hirschman tem como referência o clássico estudo de T. H. Marshall sobre o desenvolvimento histórico dos direitos de cidadania em suas categorias básicas: a afirmação dos direitos civis com a Revolução Francesa; a introdução do sufrágio universal e a assimilação gradual dos direitos econômicos e sociais.

${ }^{16} \mathrm{O}$ mito grego teria sido secularizado, com sinal trocado, por Adam Smith em sua doutrina da mão invisível, onde a ambição individual, multiplicada, propicia o bem coletivo. Retomaria seu sentido original com a tese das "consequências indesejadas" tão ao gosto dos opositores da Revolução Francesa, por permitir a associação do terror jacobino ao impulso inicial de defesa dos direitos individuais. Hirschman encontra parentesco, ainda, entre a tese da perversidade e o complexo da "fracassomania" que percebia latente entre intelectuais e gestores públicos na América Latina.
} 
Enquanto o objetivo dos que empunham a tese da perversidade é obviamente o de inibir políticas ou iniciativas que ocasionem transformações institucionais ou sociais de relevo, o contraponto progressista costuma ser, afirma Hirschman, a defesa do mais amplo e irrestrito voluntarismo. Os progressistas estariam sempre prontos a modelar e remodelar a sociedade, ostentando a mais plena convicção na própria capacidade de fazê-lo. A inclinação jacobina pela engenharia social estaria comumente associada ao sentimento de que se vivencia uma situação-limite (desperate predicament) que reclama a substituição da ordem vigente por outra, radicalmente nova.

A tese da futilidade sustenta que determinadas normas e iniciativas estão fadadas à ineficácia por desconsiderarem traços essenciais da realidade que se busca transformar. De uso tão prolífico quanto o argumento da perversidade, foi explicitada por Alexis de Tocqueville com o juízo de que as 112 supostas conquistas do ciclo revolucionário já estavam incorporadas, por obra do antigo regime, à paisagem francesa, o que subtraía sentido à gesta de $1789^{17}$. Para Hirschman, a tese tem um impacto mais desconcertante sobre os reformistas do que a da perversidade, uma vez que, levada ao paroxismo, nega a possibilidade de intervenção sobre a realidade.

A resposta progressista à tese da futilidade implica também ceticismo quanto ao alcance da ação humana. Enquanto

\footnotetext{
${ }^{17}$ Hirschman lembra que Gaetano Mosca e Vilfredo Pareto também lançaram mão da tese na oposição que fizeram ao sufrágio universal e ao sistema representativo, que não se coadunariam com o postulado de que as sociedades estão desde sempre fadadas à divisão entre uma minoria de governantes e uma maioria de governados, entre a elite e a não elite. Pareto empenhou-se, ainda, em desacreditar políticas de redistribuição de renda. A partir de dados que reuniu a respeito de vários países em diferentes épocas, enunciou que os padrões nacionais de distribuição de renda tendem à uniformidade e são, portanto, impassíveis de correção por mecanismos fiscais, desapropriação ou políticas de bem-estar. George Stigler, Milton Friedman e Marin Feldstein também se encarregariam de criticar medidas redistributivas, agora sob o argumento de que, por razões diversas, elas jamais alcançavam os reais necessitados, e sim os estratos médios e, até mesmo, afluentes.
} 
os conservadores cultivam o refrão de que as coletividades são regidas por "regularidades" que lhes conferem estabilidade e inibem reformas, a esquerda é propensa a cunhar leis que impulsionariam as sociedades de maneira inelutável em uma direção específica ${ }^{18}$.

Dos três arquétipos cunhados por Hirschman, a tese da ameaça é talvez a mais moderada: novas reformas são desestimuladas por comprometerem conquistas prévias tão ou mais valiosas do que aquelas agora perseguidas. São citados os debates parlamentares que precederam a adoção das leis eleitorais - de 1832 e 1867 - que transformaram a Inglaterra de oligarquia em democracia, em particular o entendimento então expresso por muitos de que tais normas colocariam em risco as prerrogativas individuais, como o direito à propriedade ${ }^{19}$. Contribuiu para o prestígio dessa tese a associação com mitos culturais, como o ceci tuera cela (a que recorreram Victor Hugo e Marshall McLuhan) e a noção de que as mudanças sociais representam sempre um jogo de soma zero.

A reação da vanguarda à tese da ameaça consistiria na "ilusão da sinergia”, na suposição de que as novas e as anti-

\footnotetext{
${ }^{18}$ Hirschman fala de uma aspiração incontida dos cientistas sociais por emular as ciências naturais, o que se teria manifestado na reverência que Helvécio nutria por Newton e, sobretudo, na determinação de Marx em rastrear os traços de uma lei motora do processo histórico, que poderia ser abreviada, mas jamais abolida ou revista pelo engenho humano.

${ }^{19}$ Hirschman recorda que a tese foi usada contra o Estado de bem-estar social em, pelo menos, dois momentos. Nas duas primeiras décadas após o seminal Beveridge Report, em 1942, a principal referência foi Friedrich Hayek, que se estendeu em "O caminho para servidão" e "Os fundamentos da liberdade" sobre o juízo de que as políticas públicas, pela impossibilidade de serem consensuais, requerem coerção por parte do Estado sobre as vozes dissonantes. Gozou de repercussão limitada diante do reconhecimento generalizado de que as redes de proteção social haviam contribuído, no pós-guerra, para o reforço da paz social e da própria democracia. A tese voltou a constar da agenda pública no final dos anos de 1960 e início dos 1970. Obteve maior ressonância por coincidir com momento de instabilidade política na Europa e nos Estados Unidos. Expressa por nomes como Samuel Huntington, atribuiu uma alegada crise da democracia ao excesso de demanda por serviços e bens sociais.
} 
gas conquistas hão de interagir positivamente. Estaria inscrito no temperamento progressista desde a Grécia antiga a propensão a acreditar que "as boas coisas vão juntas", que os valores positivos reforçam-se mutuamente. Uma manifestação atualizada desse sentimento, afirma Hirschman, é a defesa do Estado do bem-estar pelo argumento de que este seria indispensável para salvar o capitalismo de seus próprios excessos, como o desemprego, as migrações em massa e a desintegração das comunidades e dos sistemas familiares. Ao permitir uma reprodução equilibrada do capital, as políticas sociais concorreriam também para a sustentabilidade das instituições democráticas.

Albert Hirschman, no capítulo final de The rhetoric of reaction, esclarece que, ao proceder ao mapeamento de arquétipos da retórica conservadora e de contrapontos progressistas, não quis negar que essas teses possam ser validadas em situações concretas. Não é incomum, acrescenta o 114 ensaísta, que iniciativas provoquem efeitos contrários aos desejados, sejam inócuas ou comprometam ganhos previamente alcançados. Mas Hirschman está convencido de que, pela recorrência com que foram usados à revelia dos fatos ao longo dos séculos XIX e XX, para os mais diferentes fins, os argumentos são motivados, prioritariamente, pelo apelo que lhes confere a remissão a mitos e fórmulas consagradas. Constituiriam recursos retóricos dos mais úteis a agentes políticos interessados em esquivar-se da transitividade e da incerteza inerentes ao exercício cotidiano da democracia.

Vejamos um breve apanhado de quão assíduo foi o emprego das teses da perversidade, da futilidade e da ameaça, e qual o modo como foram formuladas nos debates da (e a respeito da) ANC, com foco nas tratativas atinentes aos direitos sociais, pelo interesse despertado entre os parlamentares e junto à opinião pública. As fontes são as atas da comissão sobre direitos e garantias individuais, da comissão sobre a ordem social e, sobretudo, da comissão de sistemati- 
zação. Também serão considerados livros e artigos de algumas das lideranças do processo constituinte, bem como editoriais dos principais jornais e material produzido por foros de debates e outras instâncias da sociedade civil ${ }^{20}$.

Contra os direitos sociais, foi disseminado no processo constituinte o recurso à tese da perversidade. Das assertivas contundentes e doutrinariamente fundamentadas de Roberto Campos, em que não faltavam alusões a Hayek e Von Mises, a juízos mais insuspeitos como os de Fernando Gasparian (PMDB), passando por editoriais de $O$ Estado de S. Paulo e declarações de constituintes tais como Luis Roberto Pontes (PMDB), Delfim Neto (PDS), Ricardo Izar (PFL), Francisco Dornelles (PFL), Sandra Cavalcanti (PFL), Afif Domingues (PL) e Álvaro Valle (PL), grassou no plenário e fora dele o argumento de que o capítulo social da Carta deixaria os brasileiros mais pobres e não menos. Campos chegou a falar de "Constituição contra os pobres", contrapondo-se à denominação dada por Ulysses Guimarães de "Constituição-cidadã" ou "Constituição dos pobres". As razões variavam segundo o dispositivo constitucional. Os alvos mais visados foram a garantia da estabilidade no emprego e o teto da jornada de trabalho em 44 horas semanais.

A estabilidade no emprego traria como consequências a apatia, a baixa produtividade, a inibição dos investimentos e a consequente perda de postos de trabalho. Particularmente vitimadas seriam as pequenas e médias empresas, exatamente aquelas que mais geram empregos. Bem mais salutar econômica e socialmente - ponderavam constituintes

\footnotetext{
${ }^{20}$ Fiz uma análise mais detida do discurso constituinte segundo o instrumental desenvolvido por Albert Hirschman em tese de doutoramento submetida em 1998 à Universidade de Cambridge (Costa, 1998).
} 
tais como Dornelles e Domingos - , seria a valorização pela ANC do princípio da rotatividade no emprego, ressalvada a prerrogativa de indenização em casos de demissão sem justa causa (Brasil, 1988a, pp. 1148, 1172). As críticas à carga semanal de 44 horas estendiam-se, o mais das vezes, ao limite de 6 horas para trabalho em "horário corrido" e ao incremento de $50 \%$ no pagamento de horas extras. Vaticinava-se que, pelo ônus adicional imposto aos custos de produção, sobretudo na área de serviços e dos setores industriais menos consolidados, tais inovações afetariam negativamente o nível geral de emprego e a taxa de inflação. Valle (1987, p. 4), Campos (1990, p. 145) e o Estado de S. Paulo (1988b, p. 3) acentuaram a suposta incompatibilidade dos direitos com o estágio de desenvolvimento do país, que requeria mais e não menos trabalho. Foi lembrado que a redução na Europa do número de horas no trabalho ocorreu em função do aumento de produtividade e não 116 por fiat legislativo. Também foram feitas comparações com o Japão e a Coreia, onde, malgrado os elevados índices de produtividade, prevaleciam limites de horas semanais bem superiores ao nosso. O Brasil estaria na contracorrente de seus competidores ${ }^{21}$.

Não foram poucos os argumentos sob o lema da perversidade que aspiravam à precisão de enunciados científicos. Os resultados deletérios para a população que adviriam

\footnotetext{
${ }^{21}$ Dispositivos menos controversos também sofreram restrições com base na tese da perversidade, como os relativos à licença-maternidade e à proibição do trabalho infantil. Roberto Campos chegou a qualificar a licença como uma medida antifeminista, tamanho o desestímulo econômico que traria a uma maior presença das mulheres no mercado de trabalho (Campos, 1987, p. 9). Sandra Cavalcanti, por sua vez, via a proibição do trabalho infantil como contrária ao esforço de proteção de crianças e adolescentes contra o apelo da criminalidade e marginalização. Impedidos de exercerem uma atividade produtiva, tornar-se-iam presas fáceis do crime organizado. $\mathrm{O}$ arremate do argumento não podia ser menos feliz: para a parlamentar fluminense, se a proibição em tela estivesse vigente nos séculos anteriores, o Brasil teria sido privado do talento de Machado de Assis e de Aleijadinho, que começaram a trabalhar em idade tenra (Brasil, 1988a, p. 1295).
} 
do capítulo social da Carta foram, por vezes, apresentados como efeitos negativos e inelutáveis da aplicação das normas. Outra não foi a linha, por exemplo, dos prognósticos feitos pelo O Estado de S. Paulo sobre a repercussão das cláusulas sociais. Em editorial, o jornal ateve-se ao tema da licença-paternidade e corroborou equação elaborada por Delfim Netto segundo a qual, a cada ano, por conta daquela prerrogativa constitucional, 100 mil homens perderiam seu posto de trabalho (O Estado de S. Paulo, 1988c). Em outro editorial, Mellão Neto, por sua vez, voltou-se para o elenco de direitos sociais e chegou a estimar um impacto imediato de $25,4 \%$ sobre a folha salarial das empresas brasileiras, que cairia, a médio prazo, para a porcentagem tampouco negligenciável de 15,8\%. Com os direitos convertidos em questão técnica, de efeitos mensuráveis, as vozes dissonantes são facilmente qualificadas de ineptas. Campos (1987, p. 9) foi mais além e, no espaço de um só artigo, reportou-se à esquerda dominada, segundo ele, por "cretinismo catedralesco", "hemiplegia" e "parálise mental".

A resposta da esquerda no processo constituinte à tese da perversidade revelou-se condizente com o parâmetro reconstruído por Hirschman, naturalmente ajustado às circunstâncias locais. A avalanche de alertas quanto às consequências indesejadas das normas sociais teve como contraponto um voluntarismo maximalista justificado pela alegada iminência de um desastre político e social. Tal cenário somente seria evitado com a adoção de uma Carta que previsse meios para uma correção intempestiva de iniquidades históricas, o que, por sua vez, pressupunha a condução do processo pelos oprimidos de hoje e de sempre, dotados, por sua condição, de legitimidade e clarividência.

Florestan Fernandes (PT) sobressaiu-se como intérprete da situação de risco em que se estaria realizando a Constituinte (Fernandes, 1986, pp. 67-77). Amparado, como sociólogo, na caracterização que fizera do "capitalismo sel- 
vagem" em vigência no Brasil, Florestan mostrou-se indignado com o desinteresse das classes dirigentes em buscar soluções, ainda que burguesas, para as assimetrias do sistema capitalista no país. Nos anos anteriores, o quadro de exclusão social ter-se-ia, na verdade, agravado. Não se observara movimento algum no sentido de resgate das pendências que se haviam multiplicado desde a extinção do regime escravocrata, passando pela Proclamação da República, pela aliança liberal de 1930 e pelo populismo dos anos de 1950. Não houvesse por parte da ANC a decisão de romper não apenas com o "entulho autoritário" do período ditatorial, mas também com os padrões atávicos de exploração social, Florestan via como risco concreto a hipótese de eclosão de uma guerra civil $^{22}$.

A leitura prevalecente no campo progressista era a de que a Carta deveria prever instrumentos que assegurassem sem delongas a transformação social, a "revolução dentro 118 da ordem”, na linguagem de Florestan. Não faltaram ideias nesse sentido. Uma das propostas que gozou de maior apelo foi a de que se adotasse o instituto de "inconstitucionalidade por omissão", defendido com veemência por José Paulo Bisol (PSB) e Lysâneas Maciel (PDT), com o apoio de nomes como Cândido Mendes e Márcio Thomaz Bastos (Brasil, 1987a, p. 71; Brasil, 1987f, p. 21 e Brasil, 1987a, p. 72 e 99). Eram citadas, como antecedentes relevantes, as constituições espanhola e portuguesa, em que são contemplados, para o Legislativo, a obrigação de não se eximir

\footnotetext{
${ }^{22}$ Com tom menos apocalíptico, Hélio Jaguaribe não deixou de sublinhar a necessidade de que fossem criadas condições para um tratamento imediato da questão social. Atribuiu ao autoritarismo tecnocrático-militar o acirramento da disparidade entre a burguesia, com condições de vida "ocidentais", e as massas, sujeitas a circunstâncias "asiáticas". Lembrava que os $10 \%$ mais afluentes detinham mais de $50 \%$ da renda nacional. A persistência de padrões tão iníquos de desigualdade seria incompatível com a democracia. Caso perdurassem, Jaguaribe estimava como certo o retorno ao autoritarismo, de direita ou de esquerda (Jaguaribe, 1985, p. A3).
} 
da produção de norma complementar quando necessária para a eficácia do texto constitucional e, para o Executivo, o dever de não se privar da realização dos atos administrativos devidos para a operacionalização da Constituição ou de norma ordinária superior. Mas tinha-se em vista algo mais. Desejava-se a efetiva garantia pela Carta da implementação dos direitos econômicos e sociais. Se constatada a indisponibilidade de meios para assegurar o usufruto imediato por todos de determinados bens, como o direito a uma existência digna, o Estado deveria ser compelido a redefinir prioridades e adotar políticas dirigidas à consecução no mais breve prazo possível das garantias constitucionais ainda não satisfeitas.

O juízo final sobre a omissão ou não do Estado na provisão de meios para o usufruto generalizado dos atributos constitucionais ficaria a cargo de um "tribunal de garantias da soberania popular e dos direitos constitucionais", que não se confundiria com o Supremo Tribunal Federal, inclusive no que concernia à composição. Os membros da Corte constitucional paralela deveriam dispor não apenas de reputação ilibada e conhecimento jurídico, mas comprovar sensibilidade, sabedoria e experiência popular. Para Lysâneas Maciel, pelo menos três dos magistrados deveriam ser egressos da classe trabalhadora e demonstrar "compromisso real" com sindicatos e organizações populares (Brasil, 1987b, p. 6).

Florestan Fernandes foi claro na caracterização de quem deveria construir e reger o Brasil do futuro, a começar pela definição da nova ordem constitucional: os proletários do campo e da cidade, universo variado constituído pelo indígena, pelo negro, pelo professor humilde e por todas as demais categorias sociais que se viram ao longo da história "banidas da nação" ou "reféns de uma falsa cidadania”. Do âmago da iniquidade social brasileira viriam os redentores do país (Fernandes, 1987a, p. 3). Jair Meneguelli, então presidente da Central Única dos Trabalhado- 
res, ecoava o mesmo sentimento (Meneguelli, 1987, p. 111). Se a Constituinte almejava mudar o Brasil, o protagonismo deveria caber às vítimas do sistema e não aos latifundiários, banqueiros e homens de negócios em geral ${ }^{23}$.

O voluntarismo normativo da esquerda sofreu críticas acirradas de Roberto Campos e seus pares segundo a tese da futilidade. Se aprovadas pela ANC, grande parte das propostas socialistas resultaria inócua, sem impacto algum sobre a condição de vida dos brasileiros, diluindo a relevância prática da nova Carta, que se assemelharia a um "dicionário de utopias", a um simples "mosaico de aspirações". Pleitos que, sob a chave da "perversidade", eram combatidos por provocarem consequências opostas às pretendidas, como a estabilidade no emprego, cláusula supostamente 120 geradora, pelo custo adicional que impunha às empresas, de mais demissão e maior desemprego, agora se tornavam reivindicações cosméticas, esvaziadas de sentido. Em um mercado de trabalho em que a informalidade era crescente, a imposição da regra de estabilidade cairia no vácuo ou, o que seria ainda pior, estimularia a disseminação de relações de trabalho ao desabrigo da lei, reduzindo, com isso, o espaço para observância de qualquer das novas conquistas sociais.

Prerrogativas como salário mínimo unificado, irredutibilidade de salários, redução de horas de trabalho, licen-

\footnotetext{
${ }^{23}$ A Pastoral da Terra era mais seletiva. Como verbalizado por seu líder no Paraná, Werner Fuchs, considerava os proletários do campo melhor situados do que os proletários da cidade para questionar o estado de coisas existente. Os trabalhadores urbanos restringiam a luta pelo socialismo à reivindicação salarial. Já os rurais, sujeitos a uma situação de quase aniquilamento, questionavam os meios de produção e a propriedade privada. Sem prejuízo da necessidade de alianças, dos últimos dependeria o impulso para uma transformação radical a favor de um novo tempo (Fuchs, 1987, p.102).
} 
ça maternidade de 120 dias, licença-paternidade, proteção contra a automoção, isonomia salarial entre relações permanentes e provisórias de trabalho e universalização dos direitos à educação e saúde estariam fadadas a tornarem-se letra morta em um país onde mais de $50 \%$ da população economicamente ativa era desprovida de contrato e não contribuía para a previdência social. Se a isso fosse acrescido o custo que os novos direitos, em uma situação recessiva, impunham ao empregador, afirmava Roberto Campos, o cadinho estaria criado para uma situação de descumprimento generalizado da Constituição. Seria o tributo a ser pago pela tentativa de criar um sistema de segurança social sueco com recursos moçambicanos, ironizava, com tato questionável, o antigo embaixador brasileiro ${ }^{24}$.

Cumpria questionar a razão de tamanho irrealismo, acrescentava Campos, o qual já apresentava uma resposta: a cultura política brasileira continuaria impregnada de uma crença atávica na onipotência da lei, em linha com a mentalidade juridicista que havia desde sempre orientado a formação da elite nacional. Quando a tal crença se somava uma ilusão distributivista, o resultado era a produção de normas sem qualquer fundamentação econômica. Despesas eram previstas sem a identificação das receitas correspondentes. Benefícios eram dados à revelia de aumentos de produtividade. Daí a ineficácia contumaz dos exercícios de "caritocracia" representados pelos processos constituintes na América Latina, os quais, até por conta disso, multiplicavam-se ${ }^{25}$.

\footnotetext{
${ }^{24}$ Esses comentários foram extraídos de Campos (1988b, p. 2, 1988a, p. 7, 1994, pp. 1206, 1075-80 e 1184).

${ }^{25}$ Em suas memórias, Roberto Campos menciona a média de 13 Constituições por país desde a respectiva Independência. A "incontinência" constituinte mais aguda teria ocorrido na República Dominicana, Venezuela e Haiti, com 20 Cartas cada. O Brasil, assim como o México, estava abaixo da média, com 8 textos, mas plenos de passagens inusitadas, como a previsão na Constituição de 1988 de que esta seria revista em um par de anos. Nossos constituintes, concluía Campos, não poderiam ter sido mais explícitos na admissão de que a obra realizada havia sido das mais precárias.
} 
Muitas vozes fizeram coro à litania de Roberto Campos contra a crença no poder demiúrgico da lei, a começar pelos órgãos de imprensa. O Estado de S. Paulo caracterizava o exercício constituinte como uma era dourada marcada pelo animus dândi dos parlamentares, indiferentes como eram à eficácia dos fins a que estavam destinando os recursos coletados do contribuinte. Mover-se-iam, os parlamentares, por seus cálculos eleitoreiros imediatos, sem o menor pejo em atribuir a responsabilidade pela ineficácia das normas a quem não conseguia aplicá-las enquanto empregador, seja na esfera pública, seja na esfera privada. O jornal destacava o irrealismo representado pela licença paternidade e pelos quatro meses de licença-maternidade, traçando paralelo com a prática indígena da couvade, com a diferença de que, entre os nativos, o pai repousava ao passo que a mãe logo retornava ao trabalho (O Estado de S. Paulo, 1988a, p. 3).

122 Já a Folha de S. Paulo reportava-se ao projeto da Carta como um compêndio permeado de boas intenções, mas na qual não se evidenciava preocupação alguma com a aplicabilidade do ali disposto. Buscava-se resolver pela via legislativa problemas de naturezas muito diversas: a carência de instituições democráticas e uma imensa dívida social. Enquanto o primeiro poderia ser encaminhado "formalmente" mediante uma adequada construção constitucional do regime de governo, das relações entre os poderes e do sistema eleitoral, o segundo, para seu equacionamento, reclamava, ao invés de normas, políticas públicas e fiscais eficazes. Persistindo no equívoco de situar não somente o primeiro desafio, mas também o segundo como matéria constitucional, os constituintes produziriam uma Carta com baixo assentamento social, validade incerta e grande superficialidade (Folha de S. Paulo, 1987a, p. A2).

Se o discurso conservador situava o ativismo social dos constituintes como indicativo de um bacharelismo tão atá- 
vico quanto inoperante, o tempo em que se reunia a ANC não era visto como estático ou sem promessas. Pelo contrário, era apresentado como um tempo de grandes transformações, ou, mais precisamente, como um tempo no qual se podia discernir uma tendência arrebatadora rumo à afirmação do mercado como regulador da vida econômica e social e ao consequente recuo do Estado. A exigência maior que tal momento impunha à ANG seria o de liberar o país de suas amarras regulatórias e orientá-lo na direção que já era perseguida por todos, desde as sociais-democracias europeias aos redutos onde até havia pouco imperava o "socialismo real", que se desconstruía sob o impulso de Gorbachev. Seria de todo extemporâneo recuar no tempo em busca de inspiração e tentar montar no Brasil dos anos de 1980 um Estado do bem-estar social.

A inocuidade dos direitos sociais passava a ter, assim, uma segunda explicação. Além do culto à onipotência da norma, uma variável duradoura, supostamente associada à cultura política brasileira e latino-americana, sobressaia agora o descompasso com o fluxo da história, necessariamente dinâmico. Uma vez mais, Roberto Campos ditou o compasso do discurso conservador, rejeitando a caracterização do debate como um confronto entre direita e esquerda. A tensão se daria, na verdade, entre arcaicos e modernizadores, o que, no Brasil, assumia contornos específicos. Ao contrário do pregado por Florestan, o país não se encontraria sob o domínio nefasto do capitalismo, que, selvagem ou domesticado, jamais lograra implantar-se no país. Vigia entre nós um sistema prévio de acumulação de riquezas, que mais se assemelhava a um mercantilismo notarial. Sem um corte claro com esse passado, que saudasse as benesses do mercado, não haveria futuro. Caberia ao Brasil compreender e seguir o rumo da história ou sofrê-la como destino, sentenciava Campos (1985, p. 8), citando José Guilherme Merquior. 
Outras vozes na mesma linha fizeram-se ouvir, fora e dentro da ANC. Colunistas de O Estado de S. Paulo e personalidades como Ives Gandra Martins reverberaram o alerta contra a opção alegadamente obsoleta do Estado-previdência, modelo gerado nas circunstâncias únicas do pós-guerra europeu, quando o crescimento econômico contínuo permitiu confluência mutuamente benéfica entre capital e trabalho (Amaral Júnior, 1988, p. 2; Martins, 1988, p. A3). Já Celso Bastos falava de uma retomada inconsequente do nacionalismo dos anos de 1920, referência de todo injustificada diante dos reclamos atuais por eficiência e criatividade (Bastos, 1988, p. A3). A Folha de S. Paulo (1987b, p. A2) pleiteava a reconsideração de teorias arraigadas no país, tais como o estatismo, e aludia às mudanças em curso na União Soviética. Albano Franco (PFL) era insistente na defesa da desregulamentação da economia e citava a ameaça de isolamento no concerto das nações (Brasil, 1987e, 124 p. 108). Álvaro Valle (PL) afirmava que as fórmulas de que lançava mão a esquerda no combate à pobreza somente estavam em voga em alguns países que, na América Latina e na África, mantinham-se alheios à onda de liberalização (Valle, 1987, p. 4).

Para nomes de destaque na esquerda, a história caminhava na direção contrária e com passo igualmente inelutável. Florestan distinguia-se pela contundência. Atribuía à ANC a responsabilidade de recolocar o país no trilho regular do processo histórico, no qual, a bem da verdade, nunca estivera, por falha da burguesia em realizar suas "revoluções": a nacional, a agrária, a urbana e a democrática. Era chegado o momento de romper o nó górdio que atava o futuro do Brasil ao passado colonial e escravocrata. O "Frankenstein político" representado pela chamada Nova República somente acirrara o quadro de exclusão social e concentração de riqueza que caracterizava a vida nacional desde a Independência, onde a nota fora a práti- 
ca das "conciliações por cima". Como ponto de partida de uma sempre devida evolução histórica, a Assembleia ANC o gatilho da ruptura indispensável à construção de uma "nova era", inclusiva, equânime e soberana (Fernandes, 1986, pp. 88, 90, 171-2).

Theotonio dos Santos retomou o argumento da vontade coletiva à espera de um tradutor, que não poderia ser outro exceto a ANC. Falava de um momento fundacional. A nação brasileira havia sido até àquele uma ficção, por conta do caráter excludente de nosso percurso histórico. Da maioria de não cidadãos da Monarquia ao império do grande capital sob o regime militar, passando pelo patrimonialismo da República Velha, a autocracia de Vargas e o liberalismo vazio dos anos de 1950, a tônica fora o alijamento do povo das decisões. A ANC passaria a limpo esse passado, como marco de uma nação que despertava de uma longa letargia com um profundo sentimento de generosidade em relação a seu futuro, democrático, plural e humano (Santos, 1986, p. 157). Maria Victoria Benevides também apostava na soberania popular, por frustrada que tivesse sido, em nome do pragmatismo, durante a transição. A ANC, idealmente exclusiva, poderia e deveria ser um momento de ruptura para a instauração de uma nova ordem política, jurídica, econômica e social (Benevides, 1987, p. A3).

Avançados os trabalhos da ANC, Florestan Fernandes não escondeu seu desalento com os resultados, que teriam frustrado suas mais realistas expectativas. A Constituinte deixava muito a desejar. Não estaria propiciando a esperada revolução dentro e por meio da lei. Pela corrupção e pela influência do capital, a minoria impusera-se à maioria, inclusive na definição das regras do jogo. Parcos teriam sido os reflexos concretos da participação popular, que ele, Florestan, reiteradamente incentivara. O Brasil continuaria carente de todas as revoluções burguesas. Mas, concedia o sociólo- 
go, havia uma nota positiva. A nova Carta disponibilizava aos "de baixo" direitos e garantias para prosseguir a gesta constituinte, que não chegaria a termo com a promulgação do texto. Até porque um novo horizonte de possibilidades havia sido aberto com a tomada de consciência por parte dos oprimidos da natureza de sua inserção social. Foram ativados o sentimento de classe e a luta social, até então adormecidos. Os donos do poder não haviam perdido privilégio algum, mas era improvável que continuassem a dominar ad libidum, sem resistência. É verdade que golpes ainda poderiam ser dados em nome da lei e da ordem. Mas tornara-se inesgotável a latitude de ação dos pobres como agentes históricos. Quando lograssem sepultar o passado, a eles, os desvalidos do campo e da cidade, caberia o futuro (Fernandes, 1987b, p. A3).

Mais sóbrio, Dalmo de Abreu Dallari também afirmava que o Brasil não seria o mesmo depois da Constituin126 te. Não porque os parlamentares tivessem realizado um trabalho extraordinário. Mas devido ao reconhecimento do peso de novos fatores na definição das ordens econômica e social. A principal inovação residiria na presença significativa do povo no espaço político, o que permitira a adoção pela ANC de instrumentos importantes como a iniciativa popular e o mandato de injunção. Dallari dizia-se convencido de que esses institutos, se implementados, poderiam favorecer em muito a igualdade jurídica. Haveria um longo caminho a percorrer para traduzir a isonomia em efetiva igualdade de oportunidades. Mas a direção parecia sinalizada rumo à conquista da justiça social por vias pacíficas. $\mathrm{O}$ futuro desejado não havia sido alcançado, mas se passara a dispor de elementos úteis para persegui-lo (Dallari, 1988, p. A3).

O fato é que, para nomes influentes da esquerda, o Brasil continuava em fase de transição. Em algum ponto do futuro estaria o porto de destino, que seria, dependendo do 
interlocutor, a sociedade sem classes, a democracia de massas ou a democracia política e social. Quando o país lá chegasse, o passado deixaria de constituir uma ameaça - o risco de tutela militar, de golpes, de autocracia burguesa extinguir-se-ia. No meio-tempo, caberia envidar todos os esforços para afastar os espectros do passado ou inimigos do futuro. Os conservadores não se haviam credenciado à posição de interlocutores. Eram "sementes reacionárias", "obscurantistas" ou simplesmente "aqueles do alto", cuja voz deveria ser abafada. Na verdade, eles próprios estariam empenhados em sacrificar seu destino. Tanto melhor, porque não haveria espaço para que coexistissem mesmo na democracia incompleta que se buscara construir por intermédio do exercício constituinte, decretava Florestan Fernandes (1987b, p. A3).

A tese da ameaça foi também empregada a velas soltas na experiência constituinte. $\mathrm{O}$ argumento central era o de que as cláusulas estatizantes e distributivistas comprometeriam a governabilidade e poriam em risco os avanços políticos realizados durante a transição. A liberdade política e a liberdade econômica eram apresentadas como valores indissociáveis entre si, pelo menos em uma escala temporal mais ampla. Seria insustentável, assim, o quadro observado nos anos de 1980, quando evoluíram em direções contrárias. O país dera passos largos rumo ao usufruto das franquias públicas. Faltariam apenas arremates institucionais a favor de uma tradução mais apurada do princípio representativo e de uma relação mais equilibrada entre os poderes. Já no plano econômico ter-se-ia assistido, em meio à escalada inflacionária, a um autoritarismo burocrático crescente, que a Constituinte ameaçava agravar.

Não faltavam antecedentes históricos a recomendar a afinidade entre liberdades públicas e livre-mercado. Rober- 
to Campos recordou a celeuma na Itália pré-fascista entre Luigi Einaudi e Benedetto Croce. Enquanto o primeiro viu desatendida sua posição de que a liberdade econômica era condição sem a qual a liberdade política não prosperaria, Croce insistiu, com maior ressonância na opinião pública, na diferença entre liberalismo e liberismo, apenas para presenciar, impotente, a ascensão do fascismo (Brasil, 1987d, pp. 50-1). Campos aludiu também ao "distributivismo populista” de Vargas e Perón, em que a sinergia não poderia ter sido mais evidente entre autocracia e estatismo. Um atributo comum a ambos havia sido o desconhecimento absoluto de economia. O líder brasileiro não fora capaz de distinguir salário nominal de salário real, ao passo que seu colega argentino considerava o Erário uma fonte inesgotável de prebendas às massas (Campos, 1988a, p. 7, 1987, p. 9).

Uma lástima que tais exemplos reverberassem por décadas a fio e chegassem a inspirar "cretinismos catedralescos" 128 como os que estariam sendo cometidos pela comissão da ordem social e pela própria comissão de sistematização da ANC, asseverava Roberto Campos, com o endosso de O Estado de S. Paulo e um bom número de constituintes. Corroboravam a preocupação do presidente José Sarney com o risco que a enxurrada de novos direitos em ambiente de escassez poderia trazer à governabilidade. Estariam comprometidos, pelo desvio de recursos, não apenas projetos questionáveis como a ferrovia Norte-Sul, afirmava o jornal, mas a própria execução de políticas públicas. A vítima maior, contudo, seria a comunidade empresarial. Seria tal o desestímulo causado à atividade produtiva pelo acúmulo de novas obrigações sociais que se prenunciava um descumprimento generalizado da lei, com reflexos imprevisíveis sobre a estabilidade institucional (O Estado de S. Paulo, 1988d, p. 3).

Nada mais benfazejo, assim, do que a oportunidade oferecida pelo Centrão de revisão do regimento interno da $\mathrm{ANC}$ para que o plenário opinasse sobre os excessos cometidos 
pela esquerda na primeira etapa do processo constituinte. Bonifácio de Andrade (PDS), um dos líderes do agrupamento interpartidário, dava guarida às expectativas de contenção da "onda rosa". Mostrava-se veemente na crítica à sujeição da iniciativa privada à tecnocracia e ao autoritarismo administrativo. Por métodos antidemocráticos, a comissão de sistematização teria criado um quadro normativo de todo refratário à liberdade e ao progresso econômico. Cumpriria agora tornar o projeto de Carta menos ideológico e mais conforme a "evolução do nosso povo" (Andrade, 1988, p. 7). O veto do plenário à possibilidade de reforma agrária em latifúndios produtivos foi muito celebrado. Só que logo veio o desapontamento com a preservação de grande parte das cláusulas sociais, incluindo aquelas julgadas mais onerosas para o setor produtivo, como a estabilidade no emprego, a jornada de 44 horas e a licença-maternidade de 120 dias. Não se esperava a inusitada convergência de parte do Centrão com a esquerda a esse respeito. O Estado de S. Paulo (1988c, p. 3) lamentou o predomínio que se teria observado da emoção sobre a consistência doutrinária (1988c, p. 3). Álvaro Valle (PL) advogou, como remédio último, a devolução pelo plenário do Poder Constituinte ao eleitor, com a convocação de eleições gerais (Valle, 1987, p. 4). Roberto Campos chegou a recorrer a Bertold Brecht para traduzir a situação marginal em que se via após seguidas frustrações. Caracterizou como tragicômicos a aprovação do capítulo social e o risco imposto à governabilidade (Campos, 1988b, p. 2).

Pode parecer surpreendente a desenvoltura com que nomes até havia pouco identificados com o regime militar perfilaram-se em defesa da liberdade contra a ameaça supostamente representada pelas obrigações sociais. A explicação talvez resida no fato de que associavam o conceito, na linha dos ideólogos da "liberdade negativa", à ausência ou limitação do poder do Estado. Se o intervencionismo estatal sempre fizera parte da cena brasileira, a ANC parecia 
querer levá-lo ao paroxismo, distanciando o país ainda mais de um pretendido capitalismo democrático. Sem um Estado enxuto, que despolitizasse por completo a economia, os indivíduos persistiriam na condição de "clientes submissos", não se convertendo jamais em cidadãos, capazes de exercer livremente suas opções (Campos, 1985, pp. 112-3).

A resposta da esquerda à tese da ameaça seguiu, grosso modo, o padrão esboçado por Albert Hirschman. Ao invés de comprometer a construção em curso da democracia, os direitos sociais dariam sustentabilidade às reformas políticas e salvariam a própria versão local do capitalismo, incapaz como se mostrara até então em conciliar capital e trabalho ${ }^{26}$.

Foram vários os constituintes que se pronunciaram acerca dos benefícios que dispositivos específicos da Carta social trariam à feição do capitalismo no Brasil. José Genoíno (PT) enaltecia a relevância da estabilidade no emprego para 130 a modernização das relações de trabalho, sem qualquer dano ao "sacrossanto direito de propriedade" (Brasil, 1988b, pp. 1157-8). Nelton Friedrich (PMDB) e Luiz Salomão (PDT) apontavam a experiência japonesa como exemplo de que a estabilidade era não apenas compatível, mas também indutora de elevados índices de produtividade (Brasil, 1988b, pp. 1160, 1149). Bocayuva Cunha (PDT), Geraldo Campos (PMDB) e Brandão Monteiro (PDT), por sua vez, coincidiam em situar a jornada de 44 horas como inovação que ajudaria a elevar as práticas brasileiras aos

\footnotetext{
${ }^{26}$ Já se mencionou a aceitação por Florestan Fernandes em substituir suas aspirações mais radicais por uma "revolução dentro da ordem" que assegurasse a promoção social, ainda que parcial, do trabalhador. Uma das consequências não negligenciáveis de tal cenário seria a domesticação do capitalismo nacional, que assumiria uma face mais humana. $\mathrm{O}$ constitucionalismo brasileiro seria pródigo em fórmulas sobre como avançar nessa direção. Bastaria consulta aos escritos de Godofredo da Silva Telles, Dalmo de Abreu Dallari e Raymundo Faoro, recomendava Florestan.
} 
padrões em voga nas principais economias do mundo (Brasil, 1988b, pp. 1205, 1207, 1987c, p. 102).

Não menos professado foi o entendimento de que as obrigações sociais, ao invés de debilitarem, reforçariam a democracia. Florestan encarregou-se de colocar a questão em perspectiva. Entre as muitas lacunas observadas na evolução política brasileira, uma das mais agudas havia sido a ausência de meios para um exercício efetivo dos direitos de cidadania, a começar pelo sufrágio, que se resumia, desde sempre, a uma "técnica de domesticação política" dos mais pobres. Dele fizeram largo uso as "democracias senhoriais do Império" e as "democracias plutocráticas da República" para conferir uma aparência de consentimento a formas cruas de dominação social (Fernandes, 1986, pp. 143-208).

Severo Gomes (PMDB) era igualmente veemente no juízo de que a questão social sempre fora o principal empecilho à evolução institucional do país. A desigualdade extrema era a responsável última pela transitoriedade dos experimentos democráticos. Criara-se um círculo vicioso. Como havia sobre a mesa inúmeras carências "inegociáveis", por exemplo, a fome, exigia-se árduo e elaborado trabalho de engenharia política para arrematar compromissos, o que raras vezes ocorrera. As tensões sociais terminavam por gerar desobediência civil e abalos institucionais. Os militares intervinham em missões saneadoras cujo resultado inelutável, até por conta da repressão às demandas sociais, era o agravamento da concentração de renda e a renovação dos pleitos pela democracia. Oxalá a Constituinte pudesse gerar condições, aspirava Severo, para alterar essa sina, acelerando a correção do quadro social e permitindo, por fim, o enraizamento da democracia (Brasil, 1987f, p. 151).

Marcio Thomaz Bastos reiterava seu otimismo na capacidade de a Constituinte contribuir para superar a desigualdade social como fonte de turbulência institucional. A solução do problema somente viria pela ação geral da 
coletividade via políticas públicas. Mas o aparato normativo poderia eliminar privilégios e definir princípios para uma repartição mais equânime da riqueza. Isso em nada conflitaria com a propriedade privada ou a livre-iniciativa. Apenas aproximaria o Brasil das condições vigentes nas grandes democracias do Ocidente (Bastos, 1986, p. 156).

Se, em Severo Gomes e Thomaz Bastos, a preocupação com as condições materiais para um usufruto real da cidadania não revelava descaso com o valor intrínseco das liberdades e instituições democráticas, outros depoimentos soavam menos convincentes a esse respeito. Emir Sader distinguia entre o "invólucro vazio" representado pela definição jurídica de cidadão como sujeito de direitos e o "conteúdo essencial" que tal definição mascarava, a saber, as condições concretas de existência de cada indivíduo, fosse ele trabalhador, mulher, negro, menor, idoso ou agricultor. Se a Constituinte não avançasse também no segundo plano, 132 sua contribuição à democracia brasileira seria inexpressiva (Sader, 1986b, pp. 145-6). Jair Meneguelli foi mais além. Equiparava a democracia à justiça social e aos direitos por alimentação, saúde, educação, habitação, trabalho e um salário decente. Seriam perfeitamente dispensáveis as instituições que não assegurassem tais bens, limitando-se ao endosso de uma democracia formal que sujeita a classe trabalhadora aos interesses e caprichos dos estratos dominantes (Meneguelli, 1987, p. 111).

Sabe-se que o largo emprego de uma retórica da intransigência na ANC não impediu que o foro cumprisse seu mandato e atualizasse a ordem constitucional brasileira. É sempre possível afirmar que, sob a prevalência de padrões discursivos mais transitivos, a ANC teria produzido um texto menos ambíguo e mais autoaplicável. Quem sabe do exer- 
cício deliberativo poderia ter resultado uma Carta em que não se observasse um contraste tão marcante entre dispositivos estatizantes e princípios liberais; entre normas centralizadoras e uma ênfase federalista; entre a opção presidencialista e claras concessões ao parlamentarismo. Ou uma Carta em que grande parte de seus preceitos prescindisse, para sua efetiva observância, de legislação complementar. De todo modo, não há como fazer história "a contrapelo". Careceremos sempre dos fatos. O que sim parece claro é que a ANC evidenciou que o discurso político brasileiro, por ocasião da renovação formal do Estado de direito, estava ainda impregnado de vícios autoritários.

Não se confirmou a generalizada conversão do meio político à compreensão da democracia como um processo deliberativo autônomo, indeterminado e sem guias ou tutores. A atitude de cautela de Albert Hirschman revelou-se mais acurada do que o otimismo de Francisco Weffort quanto ao grau de sedimentação da linguagem democrática no Brasil do final dos anos de 1980. Nem a direita, nem a esquerda passaram incólumes pelo teste. Nas fontes primárias analisadas, Roberto Campos e Florestan Fernandes podem ser singularizados como os porta-vozes mais articulados de seus respectivos campos. Ainda que o discurso dessas personalidades tenha um inconfundível timbre pessoal, as posições por elas expressas revelaram-se emblemáticas da opinião de muitos de seus pares.

A título de conclusão, recordemos os principais "vícios retóricos" de conservadores e progressistas. Entre os primeiros, era corrente a leitura de que a democracia não gozaria de autonomia ou sequer sobreviveria diante do autoritarismo econômico. A afirmação da liberdade no país dependeria menos da operação das instituições representativas do que da superação do mal crônico do estatismo. Já os progressistas mostraram-se habituados a questionar a autonomia da política sob o ângulo oposto. A garantia pelo Estado de uma dis- 
tribuição mais equânime da renda era condição sem a qual a democracia não poderia prosperar. Na ausência de condições materiais para um exercício significativo da cidadania, as franquias democráticas apenas serviam para encobrir a opressão de classe ou alimentar "ilusões constitucionais".

Para um sem-número de atores de ambos os lados do espectro ideológico, a política era tudo menos um processo em aberto. Várias razões eram brandidas para explicar a absoluta previsibilidade das consequências que adviriam das inovações constitucionais. Para os adeptos da tese da perversidade, o elevado custo imposto pelas obrigações sociais produziria ao invés de bem-estar, forçosamente, desemprego adicional e indigência. Quando se preferia como recurso argumentativo a tese da futilidade, os novos direitos passavam a ser vistos como necessariamente inócuos, seja por decorrerem de uma irrealista e atávica crença do legislador na onipotência da norma, seja por

134 contrariarem a marcha da história rumo a uma crescente desregulamentação. Daí o imperativo de que os conservadores assumissem o leme da experiência constituinte e assegurassem a feitura de uma Carta operativa que garantisse a despolitização da economia. Eles, e somente eles, estariam credenciados a tal tarefa.

Para muitos nomes da esquerda a história seria guiada por leis também. O capítulo social e conquistas afins permitiriam ao país não apenas evitar um "desastre iminente", mas trilhar o caminho regular do processo histórico. Como espaço para uma "revolução dentro da ordem", a Constituinte sepultaria a Nova República e resgataria o débito acumulado ao longo do tempo com todas as revoluções burguesas. Para tanto, era imprescindível que o ritmo fosse ditado pela clarividência dos que haviam sido vítimas contumazes da história: os "de baixo" da cidade e do campo. Frustrada a oportunidade de uma Carta à imagem e semelhança dos desvalidos, ficara o ganho da emergência de uma consciên- 
cia de classe, que havia ativado a luta social e aproximaria o país aos poucos de um futuro desde sempre prescrito.

Modelos de futuro constavam igualmente do discurso conservador, só que consubstanciados no presente de outras nações, que eram situadas, dependendo do orador, ora no Ocidente industrializado, ora no Japão ou países emergentes do Sudeste asiático. Enquanto não chegássemos lá, conviria precaver-se, como também pregava Florestan Fernandes às audiências, contra os inimigos do amanhã. É verdade que, como o futuro era apresentado como uma profecia autorrealizável de hegemonia do mercado, as vozes dissidentes estavam fadadas à irrelevância. Poderiam, quando muito, arrefecer o fluxo da história nos trópicos, ampliando o hiato entre o Brasil e as demais democracias capitalistas. De todo modo, a regra era não contemporizar. Em muitos tópicos, o ponto de chegada coincidiu com o ponto de partida na interlocução dos entusiastas do mercado com os socialistas estatizantes e vice-versa. Não havia margem para transigência ou acomodação de posições. As celeumas, e houve muitas, eram diluídas em fórmulas declaratórias ou simplesmente levadas a voto.

Escapa aos objetivos deste artigo atualizar a reflexão, com eventual paralelo entre os padrões discursivos da experiência constituinte e aqueles ora vigentes. Mas não custa reconhecer que algumas mudanças são perceptíveis. Parece haver nos dias de hoje maior receptividade à concepção da política como um processo em aberto, indeterminado, até pela falência ou comprometimento de alguns modelos de futuro. Após a discussão que se seguiu à Queda do Muro de Berlim acerca dos rumos do socialismo e ao descrédito que a crise financeira internacional trouxe aos apóstolos mais empedernidos de um mercado sem regulamentação, o terreno revela-se pouco fértil para a advocacia de leis ou marchas da história. 
Focado no presente, o discurso político mostra-se também mais pragmático. No lugar da confrontação entre modelos claramente distintos de organização da sociedade e do Estado, busca-se uma acomodação viável entre o reconhecimento das leis de mercado e a valorização do papel do Estado na provisão de bem-estar e na regulação dos serviços públicos. Não se trata, obviamente, de um fenômeno restrito ao Brasil. Mas nas últimas duas décadas ganhou raízes no país pelo exercício do poder por parte de variações nativas da social-democracia. Embora poucas vezes admitida, a proximidade entre as pautas do governo e da oposição parece facilitar a administração dos conflitos e o ajuste de posições.

Mas há notas dissonantes. Uma delas é o risco de atrofia da crítica. O reconhecimento do impacto positivo sobre a economia e o quadro social da relativa continuidade observada nos últimos cinco governos em orien136 tação macroeconômica e políticas públicas, se traduzido em complacência com os gestores de plantão, pode esvaziar o debate sobre os fins e valores da ação política. Não será a razão instrumental a melhor conselheira para a definição do bem comum em um momento pleno de incertezas, quando a crise financeira cria limitações crescentes à gestão pública. Ainda bem que tal risco é temperado por um exercício cada dia mais amplo dos direitos de cidadania, inclusive por conta da diversificação em curso do tecido social.

Também cabe atenção ao empenho dos gatos pardos em diferenciarem-se entre si. O embate pode reacender tensões que na prática de governo já se encontram diluídas. A oposição chegou a abdicar da defesa de seu histórico para eximir-se de críticas ao programa de privatização. Passou a ter uma identidade clandestina e ainda não logrou construir uma nova face. Já o governo inventou uma tradição em suposto contraponto ao legado recebido, por mais 
que nele se tenha amparado, reforçando a dimensão social. Diluiu a contradição pelo carisma, com amplos ganhos eleitorais. É de lamentar-se nessa contenda a retomada ocasional de uma leitura instrumental da democracia. Alegados compromissos com a transformação social passam de elemento diferenciador de uma ou mais gestões para salvo-conduto na condução dos afazeres públicos. Em nome da transformação social, valeria tudo, inclusive a indiferença à lei e à república, como se não fossem bens que podem e devem coexistir. Mas são rompantes com ressonância limitada. Prevalece a compreensão da democracia como valor universal. Predomina o juízo de que a história não tem donos, individuais ou coletivos.

\section{Tarcísio Costa}

é diplomata e doutor em teoria política pela Universidade de Cambridge.

\section{Referências bibliográficas}

AMARAL JÚNIOR, A. 1988. "A nova carta e a ordem social”. O Estado de S. Paulo, 14 set., p.2.

ANDRADE, B. 1988. "O projeto do centrão e a realidade nacional". O Estado de S. Paulo, 24 jan., p.7.

BASTOS, C. 1988. "A nova carta já nasce velha”. Folha de S. Paulo, 10 set., p.A3.

BASTOS, M. T.1986. "Constituinte: como, quando, por quem e para quê". In: SADER, E. (org.). Constituinte e democracia no Brasil hoje. São Paulo: Brasiliense. p.156.

BENEVIDES, M. V. 1987. "A constituinte e o vulcão adormecido". Folha de S. Paulo, 8 set., p.A3.

BERNSTEIN, R. (org.). 1985. Habermas and modernity. Cambridge, MA: The MIT Press.

BRANDÃO, G. M. 1997. A esquerda positiva: as duas almas do partido comunista (1920-1964). São Paulo: Hucitec.

BRASIL. 1987a. Diário da Assembleia Nacional Constituinte, n.66, 27 mai, suplemento.

suplemento c. 
1987c. Diário da Assembleia Nacional Constituinte, n.86, 1 jul., suplemento c.

1987d. Diário da Assembleia Nacional Constituinte, n.98, 19 jul., suplemento c.

1987e. Diário da Assembleia Nacional Constituinte, n.100, 21 jul., suplemento c.

1987f. Diário da Assembleia Nacional Constituinte, n.91, 9 jul., suplemento c.

1988a. Diário da Assembleia Nacional Constituinte, 27 jan., suplemento c. 1988b. Diário da Assembleia Nacional Constituinte, n.171, 27 jan., suplemento c.

CARDOSO, F. H. 1975. Autoritarismo e democratização. São Paulo: Paz e Terra. 1993. A Construção da democracia: estudos sobre política. São Paulo: Siciliano.

CAMPOS, R. 1985. Além do cotidiano. Rio de Janeiro: Record. 1987. "Progressismo improdutivo". O Estado de S. Paulo, 20 dez., p.9. 1988a. “A vingança da história”. O Estado de S. Paulo. 28 fev., p.7. 1988b. "A Constituição promiscuísta”. O Estado de S. Paulo, 3 jul., p.2. 1990. "Razões da urgente reforma constitucional". In: MERCADANTE, P. Constituição de 1988: o avanço do retrocesso. Rio de Janeiro: 138 Rio Fundo.

1994. Lanterna na popa. Rio de Janeiro: Topbooks.

COSTA, T. 1998. A profile of contemporary political discourse in Brazil: the rhetoric of intransigence in the 1987-1988 constituent experience. Cambridge. [mimeo]

COUTINHO, C. N. 1980. A democracia como valor universal. São Paulo: Livraria Editora Ciências Humanas.

DALLARI, D. A. 1988. "Novos rumos constitucionais". Folha de S. Paulo, 10 set., p.A3.

FERNANDES, F. 1986. Que tipo de república? São Paulo: Brasiliense.

1987a. "Os trabalhadores e a constituição". Folha de S. Paulo, 2 fev., p.3. 1987b. "O uso da iniciativa popular". Folha de S. Paulo, 3 abr., p.A3.

FOLHA DE S. PAULO. 1987a. "Ficção constitucional”. 2 fev., p.A2. 1987b. "Esquerdas na constituinte". Folha de S. Paulo, 18 abr., p.A2.

FUCHS, W. 1987. "O caminho de baixo”. In: CALDEIRA, A. C. P. et al. Dossiê constituinte II: as grandes questões nacionais e as propostas populares. São Paulo: Cedi.

JAGUARIBE, H. 1985. "O novo pacto social”. Folha de S. Paulo, 2 jun., p.A3.

HABERMAS, J. 1986. Reason and the rationalization of society. In:

The theory of communicative action. v.1. Cambridge: Polity Press. 
1996. Between facts and norms: contributions to a discourse theory of law and democracy. Cambridge, MA: The MIT Press.

HIRSCHMAN, A. 1991. The rhetoric of reaction: perversity, futility, jeopardy. Cambridge, MA: HUP.

1992. Rival views of market society and other recent essays. Cambridge, MA: HUP.

1995. A propensity to self-subversion. Cambridge, MA: HUP.

KINZO, M.A. G. 1990. "O quadro partidário e a constituinte”. In: LAMOU-

NIER, B. (org.). De Geisel a Collor: o balanço da transição. São Paulo:

Sumará, pp.105-34.

MANIN, B. 1987. "On legitimacy and political deliberation". Political Theory, v.15, n.3, pp.338-68.

MARTINS, I. G. 1988. "Sobre conquistas e retrocessos". Folha de S. Paulo, 3 set., p.A3.

MELLÃO NETO, J. 1988. “Constitulices”. Estado de S. Paulo, 7 abr., p. 6.

MENEGUELLI, J. 1987. “A CUT e a constituinte”. In: CALDEIRA, A. C. P. et al. Dossiê constituinte II: as grandes questões nacionais e as propostas populares. São Paulo: Cedi.

O ESTADO DE S. PAULO. 1988a. "Uma carta irreal”, 27 fev. p.3.

1988b. "Constituição contra os trabalhadores”, 1 mar., p.3.

1988c. "Constituição das emoções", 8 mar.

1988d. "Futuro pouco promissor", 24 jul., p.3.

RAWLS, J. 1971. A theory of justice. Cambridge, MA: HUP.

1993. Political liberalism. New York: Columbia University Press.

SADER, E. 1986. "Constituinte, democracia e poder". In: (org.). Constituinte e democracia no Brasil de hoje. São Paulo: Brasiliense. pp.145-6.

SAMPAIO, P. A. 2009. "Para além da ambiguidade: uma reflexão histórica sobre a CF/88”. In: CARDOSO JÚNIOR, J. C. (org.). A constituição brasileira de 1988 revisitada: recuperação histórica e desafios atuais das políticas públicas nas áreas econômica e social. Brasília: Ipea, pp.37-50.

SANTOS, T. 1986. "Constituinte: uma agenda para o debate”. In: SADER, E. (org.). Constituinte e democracia no Brasil hoje. São Paulo: Brasiliense.

VALLE, A. 1987. "O Brasil inviável”. O Estado de S. Paulo, 1 dez., p.4.

WEFFORT, F. 1985. Por que democracia? São Paulo: Brasiliense. 